\title{
Nematocystis vinodae n. sp. (Protozoa, Apicomplexa, Eugregarinida), A Monocystid Gregarine From Eutyphoeus nicholsoni (Beddard)
}

\author{
Eutyphoeus nicholsoni (Beddard)' den Yeni Bir Monocystid Gregarin, Nematocystis vinodaen. sp.
}

(Protozoa, Apicomplexa, Eugregarinida)

\author{
Partha Mallik', Probir K. Bandyopadhyay, Bayram Göçmen² \\ 'Parasitology Laboratory, Department of Zoology, University of Kalyani, West Bengal, India \\ 2Protozoology-Parasitology Research Laboratory, Zoology Section, Department of Biology, Faculty of Science, Ege University, Bornova, Izmir, Turkey
}

\begin{abstract}
Objective: Biodiversity studies in search of endoparasitic acephaline gregarines revealed a new species under the genus Nematocystis Hesse, 1909.

Methods: The species has been obtained from the seminal vesicles of the earthworm, Eutyphoeus nicholsoni (Beddard).

Results and Conclusion: Gamonts of this species are solitary and bear a perfect nematoid appearance with smoothly curved terminals,

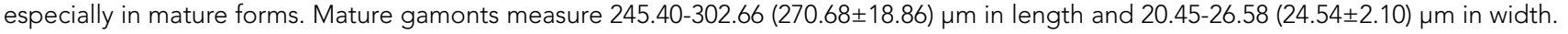
Nucleus is rounded or slightly ovoidal, 20.45-24.54 (22.69 1.74) $\mu \mathrm{m}$ in diameter. Gametocysts are almost rounded, measuring 77.71-85.89 $(82.82 \pm 2.69) \mu \mathrm{m}$ in diameter. Oocysts are navicular, measuring 7.70-8.47 (8.24 \pm 0.36$) \mu \mathrm{m} \times 4.23-4.62(4.50 \pm 0.18) \mu \mathrm{m}$.
\end{abstract}

(Turkiye Parazitol Derg 2011; 35: 27-9)

Key Words: Nematocystis vinodae n. sp., earthworm, seminal vesicles, India

Received: 10.12 .2010

Accepted: 22.12 .2010

\section{ÖZET}

Amaç: Endoparazitik asefalin gregarinlerin araştıııması ile ilgili biyoçeşitlilik çalışmaları sırasında Nematocystis Hesse, 1909 cinsine dahil yeni bir tür açığa çıkartılmıştır.

Yöntemler: Bu yeni tür Eutyphoeus nicholsoni (Beddard) türüne ait toprak solucanlarının seminal vesiküllerinden elde edilmiştir.

Bulgular ve Sonuç: Türün olgun gamontları soliter olup, bilhassa olgun formlarının düz kıvrılmış uç kısımları ile kusursuz bir nematoid görü-

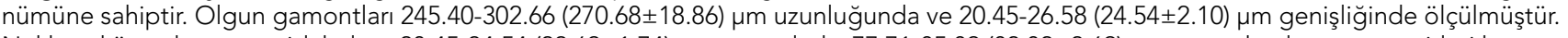

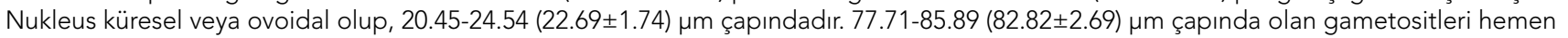

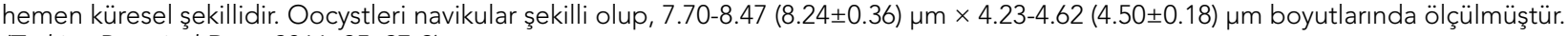
(Turkiye Parazitol Derg 2011; 35: 27-9)

Anahtar Sözcükler: Nematocystis vinodae n. sp., toprak solucanı, seminal vesiküller, Hindistan

Geliş Tarihi: 10.12.2010

Kabul Tarihi: 22.12.2010

\section{INTRODUCTION}

Nematocystis Hesse, 1909 often invade oligochaetes especially earthworms as endoparasites. Levine (1) listed 27 species of Nematocystis Hesse, 1909. Later, Segun (2) added one new species, followed by this; Pradhan and Dasgupta (3) reported five species. Roychoudhury and Haldar (4) described two new species. Bandyopadhyay and Mitra (5) established one species. Again Bandyopadhyay et al. $(6,7)$ established two new species and later Mallik and Bandyopadhyay (8) established one more new species. To date, 40 species of Nematocystis have so far been reported from oligochaete hosts, out of which 15 species have been described from India. The present paper deals with a new species of Nematocystis obtained from the seminal vesicles of the earthworm Eutyphoeus nicholsoni (Beddard).

Address for Correspondence/Yazışma Adresi: Dr. Probir K. Bandyopadhyay, Parasitology Laboratory, Department of Zoology, University of Kalyani, Kalyani 741235, West Bengal, India Phone: 741235 E-mail: prabir0432@hotmail.com doi:10.5152/tpd.2011.07 


\section{MATERIAL AND METHODS}

A survey was conducted to explore the diversity of gregarine parasites in oligochaetes of West Bengal, India,. Mature earthworms were collected and taken alive to the laboratory for the purpose. Of these, thirty-five earthworms were examined for Nematocystis infection. They were dissected while alive and their seminal vesicles were carefully removed. These seminal vesicles were placed on clean watch glass with a few drops of $0.65 \% \mathrm{NaCl}$ solution. A thin film of seminal fluid was drawn out on a slide and examination under a phase contrast microscope for live gregarine parasites. The content of the seminal vesicles was semidried and fixed in Schaudin's fluid (20 min). The fixed smears were stored in $70 \%$ ethyl alcohol for removal of mercuric chloride. The slides were then passed through a descending series of alcohol concentrations (5 min each) and placed in distilled water. These were transferred to a $3 \%$ iron alum solution (overnight) and stained with Heidenhain's haematoxylin solution (20 min). Differentiation was made with 1\% iron alum solution under the low power objective lens of the light microscope. The slides were washed thoroughly, dehydrated in an ascending series of alcohol concentrations, cleared in xylene and mounted in Canada balsam. Camera lucida drawings of different stages of gregarines were made, and photomicrographs were taken with the help of an Olympus phase contrast microscope and Olympus camera. All measurements are in micrometers $(\mu \mathrm{m})$. Description of plane shapes follows the guidelines of Clopton (9).

\section{RESULTS AND DISCUSSION}

\section{Nematocystis vinodae n. sp. (Figure 1)}

Phylum: Apicomplexa Levine, 1977

Order: Eugregarinida Leger, 1900

Family: Monocystidae Bztschli, 1882

Subfamily: Monocystinae Bhatia, 1930
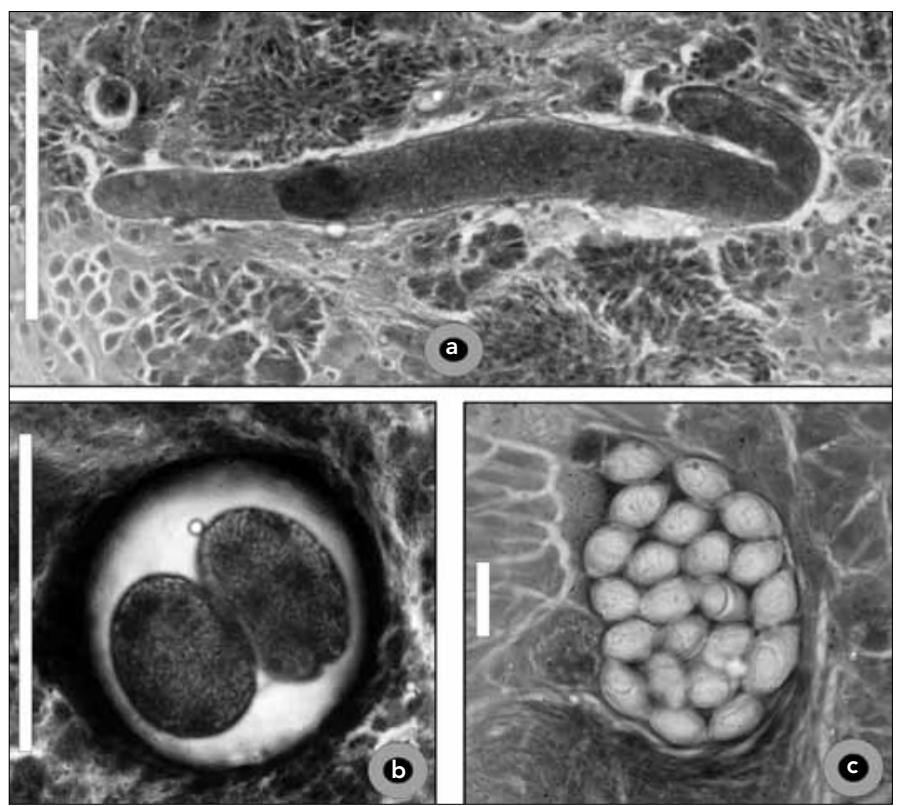

Figure 1 a-c. Photomicrographs of different stages of the life history of Nematocystis vinodae n.sp. (a) Trophozoite; (b) Gametocyst; (c) Oocysts

Scale bars: (a-b) $100 \mu \mathrm{m}$ and (c) $10 \mu \mathrm{m}$
Length of body (LB): 245.40-302.66 (270.68 18.86$) \mu \mathrm{m}$; width of body (WB): 20.45-26.58 (24.54 \pm 2.10$) \mu \mathrm{m}$; diameter of nucleus (DN): $20.45-24.54(22.69 \pm 1.74) \mu \mathrm{m}$; diameter of gametocyst (DG): 77.71-85.89 (82.82 \pm 2.69$) \mu \mathrm{m}$; length of oocyst (LO): 7.70-8.47

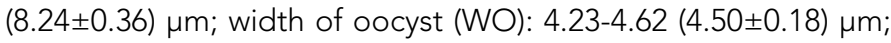
$L B: W B=11: 1 ; L O: W O=1.83: 1(n=20)$.

The characters of the genus Nematocystis Hesse, 1909 as given by Levine (1) are "Gamonts large, cylindroid, nematoid, often with mucron at anterior end, solitary, oocysts biconical". The species under consideration exhibit large gamonts, cylindrical and nematoid with little differentiated anterior end, seminal vesicles or coelome dwelling, solitary and are parasitic to earthworms. Oocysts of this species are navicular and are symmetrical. Inclusion of the present form under the family Monocystidae, the subfamily Monocystinae and the genus Nematocystis Hesse, 1909 is on the basis of the above mentioned properties.

The species exhibits some similarities with Nematocystis gardenica Bandopadhyay and Mitra, 2005 (5), Nematocystis majumdari Bandopadhyay et al., 2007 (7) and Nematocystis stephensoni Bhatia and Setna, 1926 (10). However, dissimilarities predominate. The Nematocystis gardenica possess parallel sides with pointed tips. In comparison to the present form N. gardenica is much larger in length but narrow in width. Endosarc of N. gardenica is finely granulated with uniformly distributed granules. The present form possesses an evenly vacuolated endosarc. The nucleus of $N$. gardenica is oval or elongated but the present form possess a rounded to oval nucleus. Trophozoite of $N$. majumdari is bilaterally symmetrical, elongated and wormlike with a terminal bulb-like structure. It exhibits maximum width at the terminal-bulb. The present form is perfectly nematoid, does not possess any terminal bulb, but has smoothly curved terminals. Its maximum width is at the middle of the length.

$N$. majumdari is smaller in size and its width is less in comparison to the present form. N. majumdari possesses an elongated to rounded nucleus but the present form has a rounded to ovoidal nucleus. In the case of $N$. stephensoni, gamonts elongate and are cylindrical with blunt ends. The body is highly irregular with a number of swellings and constrictions and its nucleus is ellipsoidal. In contrast, the present form is devoid of any kind of swelling. Both N. stephensoni and N. gardenica have comparatively larger gametocysts and oocysts, but the present form has a small sized gametocyst and oocyst. N. majumdari exhibit smaller sized gamonts than the present form. The species under discussion bears minor similarities with $N$. bayrami (8) regarding nuclear organization but dissimilarities are dominant. Beside these, the host of the present form is different from earlier described species.

Considering all these differences, the gregarine parasite described here is a new species and hence is designated as Nematocystis vinodae $\mathrm{n}$. sp.

\section{Taxonomic summary}

Type host: Eutyphoeus nicholsoni (Beddard).

Symbiotype: Host S/EN/05 deposited in the Museum of the Department of Zoology, University of Kalyani, Kalyani-741235, West Bengal, India.

Infection site: Seminal vesicles. 
Type locality: Fulkusma $\left(22^{\circ} 38^{\prime} \mathrm{N}, 86^{\circ} 52^{\prime} \mathrm{E}\right)$, Bankura, West Bengal, India.

Prevalance: $28.57 \%(10 / 35)$

Holotype: NS (I)/01/09 is deposited in the Museum of the Department of Zoology, University of Kalyani, Kalyani 741235, West Bengal, India.

Paratypes: $\mathrm{M} / \mathrm{NS}(\mathrm{I}) / 02, \mathrm{M} / \mathrm{NS}(\mathrm{I}) / 11$ in the collection of the Parasitology Laboratory, Department of Zoology, University of Kalyani, Kalyani 741235, West Bengal, India.

In addition to these, Slide No. 12 bearing some paratype materials has been deposited in the national collection of Zoological Survey of India, Calcutta- 53 (Reg. No. Protozoology-2487).

Etymology: This species was named after Prof. Vinod Prakash Sharma, Meghnad Saha, distinguished fellow of NASI, who has been awarded Distinguished Parasitologist Award by the World Federation of Parasitologists for his outstanding contribution in the field of Parasitology.

\section{Conflict of Interest}

No conflict of interest is declared by the authors.

\section{REFERENCES}

1. Levine ND. Revision and checklist of the species of the aseptate gregarine family Monocystidae. Folia Parasitol 1977; 24: 41-52. [CrossRef]

2. Segun AO. Monocystid gregarine parasites of Nigerian earthworms. J Protozool 1978; 25: 157-62. [CrossRef]
3. Pradhan D, Dasgupta B. Record of some new gregarines in earthworms from the hill areas of Darjeeling district-I. North Bengal Univ Rev (Sci. Tech.) 1980; 1: 135-9.

4. Roychoudhury US, Haldar DP. Studies in aseptate gregarines from earthworms of West Bengal: Two new species of Nematocystis and one new species of Stomatophora. J Beng Nat Hist Soc. (N.S.) 1984; 3: 17-27.

5. Bandyopadhyay PK, Mitra AK. Observation on two new species of Nematocystis Hesse, 1909 (Protozoa: Monocystidae) from earthworms (Annelida: Oligochaeta) of West Bengal, India. Animal Biol 2005; 55: 133-9. [CrossRef]

6. Bandyopadhyay PK, Mallik P, Mitra AK. Nematocystis indica sp. n. (Protozoa: Apicomplexa: Eugregarinida), an endoparasitic monocystid gregarine from the seminal vesicles of an Indian earthworm Amynthas diffringens Baird (Annelida: Oligochaeta). Protistology 2006; 4: 357-60.

7. Bandyopadhyay PK, Mallik P, Mitra AK. Observations on Monocystis arabindae n. sp. and Nematocystis majumdari n. sp. (Protozoa: Apicomplexa: Monocystidae) from Seminal Vesicles of an Earthworm Eutyphoeus incommodus (Beddard) from West Bengal, India. Acta Protozool 2007; 46: 147-55.

8. Mallik P, Bandyopadhyay PK. Nematocystis bayrami sp. n. (Protozoa, Apicomplexa, Eugregarinida) monocystid gregarine from Eutyphoeus orientalis Beddard (Annelida, Oligochaeta) N-W. Jour of Zool 2009; 5: 420-3.

9. Clopton RE. Standard nomenclature and metrics of plane shapes for use in gregarine taxonomy. Comp Parasitol 2004; 71: 130-40. [CrossRef]

10. Bhatia BL, Setna SB. On some more gregarine parasites of Indian earthworm. Arch Protistenk 1926; 53: 361-7. 